\title{
Driving Public Investments in Construction Sector for Economic Growth in Nigeria: A Synthesis of Wagnerian and Keynesian Hypotheses
}

\author{
Peter Uchenna Okoye \\ Department of Building, Nnamdi Azikiwe University, Awka, Nigeria \\ Received November 4, 2020; Revised December 24, 2020; Accepted January 20, 2021
}

\section{Cite This Paper in the following Citation Styles}

(a): [1] Peter Uchenna Okoye, "Driving Public Investments in Construction Sector for Economic Growth in Nigeria: A Synthesis of Wagnerian and Keynesian Hypotheses," Universal Journal of Management, Vol. 9, No. 1, pp. 1 - 12, 2021. DOI: 10.13189/ujm.2021.090101.

(b): Peter Uchenna Okoye (2021). Driving Public Investments in Construction Sector for Economic Growth in Nigeria: A Synthesis of Wagnerian and Keynesian Hypotheses. Universal Journal of Management, 9(1), 1 - 12. DOI: 10.13189/ujm.2021.090101.

Copyright $\bigcirc 2021$ by authors, all rights reserved. Authors agree that this article remains permanently open access under the terms of the Creative Commons Attribution License 4.0 International License

\begin{abstract}
This study investigated the relationship between public investments in construction sector and economic growth in Nigeria. The study deployed econometric statistics to examine the existence of Wagner's Law and Keynesian Theory in Nigeria using published economic and construction sector data. It found that federal government capital expenditure influences economic growth negatively $(t=-2.837, p(0.0084)<0.05)$, while the recurrent expenditure on construction sector has a positive and significant long-run and short-run influence $(t=10.315, p(0.0000)<0.05)$ on economic growth with a causal effect flowing from construction expenditure to GDP without feedback. The study further established that the aggregate construction investments have potential to grow the economy regardless of effects of capital expenditure $\quad((\mathrm{F}=8.19>\quad \mathrm{I}(0)=3.10 \quad$ and $\mathrm{I}(1)=3.87)$; $\operatorname{ECM}(-1)=-0.196, p=0.000<0.05))$; but for corruption, misapplication and diversion of capital project budgets. Although, this study partly confirmed the existence of Keynesian Theory, it cannot conclusively establish that construction investments stimulate economic growth in Nigeria. This signified that Nigerian economic models are defective and/or ineffective in transforming the huge capital spending on construction sector to economic growth, thereby making investment in construction sector an irrelevant strategy for economic policy formulation. It then placed the burden of economic rejuvenation through investments in construction sector on economic policy and
\end{abstract}

decision makers in Nigeria. It recommended for diligence in budgeting and implementation of capital projects as the only way the capital expenditure can contribute to a meaningful economic growth.

Keywords Construction Investment, Construction Sector, Economic Growth, Wagner's Law, Keynesian Theory

\section{Introduction}

Construction industry is generally seen as a strategic economic growth driver for any country. It serves as a foundation for social, economic and physical development. As Nigeria strives to recover from the twin economic setback occasioned by the global economic crisis, fall in the global oil market and the current COVID-19 pandemic; many economic policies and strategies have been proposed. One is the Federal Government of Nigeria (FGN) Medium-Term Economic Recovery and Growth Plan (ERGP) (2017-2020) [1]. One of the cardinal objectives of the ERGP centres on investing in infrastructure especially, construction projects for a global competitive economy [1]. However, investment attraction of construction industry development by public sector is even more strategic to all areas of the economy [2]. Both 
in the developed and developing economies, the proponents of Keynesian Theory believed that investments in construction sector would boost the nations' economy $[3,4]$.

The FGN annual capital budget, capital expenditure and recurrent expenditure on construction in the past 10 years show that the aggregate construction sector takes a huge amount of the country's annual budget every year [5-14]. On this premise, [15] argues that public expenditure in Nigeria has rapidly grown even as a share of GDP over the years through different government activities. Babatunde [16] affirms that government has continued to increase spending on infrastructure with a view to growing economy and to easing the burden of the citizens.

However, the FGN annual capital budget, capital expenditure and recurrent expenditure on construction over the years further reveal that there is an abysmal flux. This instability therefore, raises question of whether construction sector public investments actually lead or lag the overall economy in Nigeria. Furthermore, Owoeye [17] contends that inasmuch as these growths in government expenditure have been attributed to certain factors which are believed to have significantly affected the fiscal operation of the country; the huge amount is claimed by the government to have been spent on the capital projects, vis-à-vis construction growth has not been impressive. Dang and Pheng [18] attributed this to low efficiency of public investments in infrastructure construction. Babatunde [16] describes government spending on infrastructure as a waste of scare resources that is detrimental to the Nigerian taxpayers because the growth in economy does not reflect the physical really of infrastructural development. As a result, construction industry has not been listed among the major drivers of economic growth in Nigeria [19].

Meanwhile, many economic scholars have argued that investments in construction sector activities and businesses increase economic growths of a country [20-22]. Omodero [23] argues that poor funding of local industry renders it incapable of improving the economy such that the size of GDP is negatively influencing the public capital investment. However, the NBS [24] reports that Nigerian government invested heavily in the construction and infrastructure to drive growth in the country. It further reports that the sector is more optimistic towards driving the economy of the nation, because more modern construction activities have been captured with correctly deflated prices in the rebased economy [24]. In addition, while the ERGP indicates that government plans to stimulate aggregate economy through capital expenditure and investment [1]; [25] claims that the greatest impediment to Nigeria's economic growth is the gross deficit in the country's basic physical infrastructure.

On the contrary, it has been averred that government expenditure on construction sector and infrastructure seems to be detrimental to the Nigerian economy when one reflects on the indices of national development such as poverty rate and unemployment [26,27]. However, Babatunde [16] shows that government capital spending can either stimulate economic growth or retard it depending on the economic sector in which the spending was involved. The veracity of contradictory results on whether economic construction sector public investment increases economic growth in Nigeria raises more concerns and thus, requires further empirical investigation. Giang and Pheng [28] and Idris and Bakar [29] agree that the relationship between construction sector and economic growth appears more complicated than thought.

Contrasting the foregoing reality vis-à-vis the dearth of economic data and research effort on construction sector investment for policymaking, this study argues that construction sector public investment does not have significant effects on economic growth in Nigeria. Thus, there is need for further investigation into the roles of construction sector public investments on aggregate economy using the current economic data [30]. Therefore, this study was aimed at investigating the relationship between the public investments in construction sector and economic growth in Nigeria. According to Molapo [31], investment in construction infrastructure is very pertinent in the planning and economic development because of its fundamental role in the economy, and capacity of production of any country.

\section{Theoretical Framework and Empirical Review}

Girardi and Mura [32,33] have acknowledged the existence of three main strands of role of construction sector in the construction economics literature. The first strand deals with the relationship between construction sector and economic development [18,34,35]. The second strand deals with whether investment in construction sector drives gross domestic product (GDP) growth or vice versa $[3,16]$. Whereas the third strand deals with the pull and push effects of construction sector within the national economy through input-output analysis [36,37].

This current study is keyed into the second strand. As regards to this strand, the dominant application of Wagner's Law and Keynesian Theory in assessing the relationships between construction investments and economic growth is a subject of scholarship debates. Since this study is investigating the causal relationship between the public investments in construction sector and economic growth in Nigeria, Wagner's Law and Keynesian Theory are the most appropriate theoretical footing for the study.

Wagner's (1835-1917) Law of increasing state activity postulated that public expenditure is an endogenous variable and that increasing economic growth should cause increasing government investment in a long-run 
[38]. Wagner emphasised that an increase in economic expansion is seen as a function of government spending, and that the more the country experiences development, the more the government increases the financial and administrative commitment [39,40]. On this basis, Oxford Business Group [41] argues that it is the huge government spending that stimulates the construction sector growth.

Inversely, Keynesian Theory hypothesised that public expenditure is an exogenous variable and that increasing economic growth is caused by increasing government investment in a long-run [42]. That is to say that an increase in government spending is likely to lead to an increase in employment, profitability and investment through multiplier effects on aggregate demand [40]. Accordingly, the effects would provoke an increased output depending on expenditure multipliers [40]. However, the direction of causality between government expenditure and economic growth is very important for policy formulation. In the instant case, if causality runs from construction investments to economic growth (Keynes' proposition), construction investments become a vital strategy for economic policy formulation. Whereas if it is in the opposite direction (Wagner's proposition), the object of construction investments as an efficient policy tool for economic growth becomes irrelevant [43].

Empirically, scholars have expressed divergent views on whether public investments in construction sector propel economic growth or vice versa [16,20,26,44-47], and especially in Nigeria [3,19,48-53]. However, the perceived need of investments in construction sector is directly dependent on the state of economy and government fiscal and monetary policies [54].

Oladinrin et al. [19] studied the role of construction sector in economic growth in Nigeria using econometric models and found that there is bidirectional causal relation between construction output and gross domestic product (GDP). This implies that both construction output and GDP drive each other in both forward and backward directions. Aigheyisi [48] revealed that there is long-run relationship between government capital expenditure, recurrent expenditure and GDP. It also revealed that the short-run impact of each of capital expenditure and recurrent expenditure was statistically and contemporaneously insignificant, but with a lag, recurrent expenditure with negative impact exerts more influence than the capital expenditure with positive impact on the GDP. However, [55] and [56] indicated that the total capital expenditure, capital expenditure on administration, social community services and transfers have positive impact on economic growth in Nigeria. Ewubare and Maeba [57] also found that government expenditure in construction sector has significant positive long-run relationship with economic growth through increase in employment rate.

Edame et al. [50] revealed that the level of public infrastructure is not commensurate with the amount of public expenditure as shown by the amount of deterioration in the public utilities. Iheanacho [51] revealed that capital expenditure exerts a negative and significant long-run effect on the economic growth in Nigeria. A more complex relationship where a negative and significant long-run relationship and a positive short-run relationship coexist between economic growth and recurrent expenditure was also found [51].

On the other hand, [53] found that recurrent expenditures of government are significantly impacting on economic growth in a negative way while the positive impacts of public capital expenditures are not significant to economic growth. A related study by [16] indicated that government spending on transport and communication, education and health infrastructure has significant effects on economic growth; whereas spending on agriculture and natural resources infrastructure recorded a significant inverse effect on economic growth in Nigeria. Chijioke and Amadi [49] concurred with [16], while [29] revealed that positive and significant relationship exists between public sector spending and economic growth in Nigeria based on an ARDL model. A study by [58] found that an increase in capital expenditure causes a positive influence on the Nigerian economy which can be optimised through investment in rural roads and electricity. These studies therefore, supported the Keynesian theory of economic growth.

Contrarily, [40] found that there was a unilateral causal association between economic growth and government expenditure on economic services which include expenditure on construction in favour of GDP. The study then, validated the existence of Wagner's law in Nigeria. Another study conducted by [44] using ARDL to test Wagner's law in Nigeria established the existence of negative and insignificant short and long-run relationship between government expenditure and economic growth, with a larger negative effect in the long-run. Anoke et al. [59] also revealed that a negative and significant short and long-run equilibrium relationship exists between government expenditure and economic growth; but there is a positive and significant short and long-run equilibrium relationship between domestic investment and economic growth. These results however, showed a bidirectional causal relationship between government expenditure and economic growth thus, invalidating the existence of Wagner's law in Nigeria. While [44] neither suggested Wagner's law nor Keynesian theory, [59] refuted both Wagner's law and Keynesian theory.

Similarly, [60] found that government capital expenditure has negative relationship with economic growth in the long-run contrary to Keynesian proposition due to corruption in the procurement and implementation of capital projects. Study by [61] equally revealed that government expenditures on construction, transport and communication have a negative relationship with economic growth which has no impact. 
The extant literature therefore, has shown that the relationship between public expenditure in the construction sector and economic growth is conflicting. However, as a sector with multiplier effects on other economic sectors through its forward and backward linkages [62], it is imperative to investigate the government's commitment in terms of investments in construction sector and its attendant economic effects in Nigeria. In this case, this study used the federal government capital expenditure and recurrent expenditure on construction sector as factors of construction sector public investments to assess a new evidence of causal relationship between investments in construction and economic growth (GDP) in Nigeria, while testing the existence of Wagner's Law and Keynesian Theory. Hence, this is a clear departure from the previous studies.

\section{Methodology}

This study adopted an analytical research design and made use of secondary data obtained from different official publications of $\mathrm{CBN}$ and NBS. The annual statistical data from 1981 to 2019 on real GDP (LRGDP), Federal government capital expenditure (LGCEXP) and recurrent expenditure on construction sector (LREXPC) were extracted from [63-69]. These data were used to analyse the causal relationship between investments in construction sector and economic growth in Nigeria.

The stationarity of the data set was checked by conducting unit root tests using Dickey-Fuller with GLS Detrending (DF-GLS) [70], Augmented Dickey- Fuller (ADF) [71] and Phillips-Perron (PP) [72] models. These models are the most common and simplest among all other unit root models [73]. The robustness of PP and its ability to remove autocorrelation from the model are also important factors for choosing it [72,74]. For uniformity of the series, they were transformed into their natural logarithm since they were not expressed in the same unit. The logarithm values were then used to test the existence of unit roots in the series.

ARDL cointegration technique (bound cointegration testing technique) was used to investigate the stable long-run relationships between the variables in this study since the order of integration of the time series is 1 (I(1)). The ARDL model captures the dynamic effects from lagged dependent variables and other lagged explanatory variable(s), eliminating error serial correlation and avoiding the problem of spurious regression by including sufficient lags [75]. More importantly, the ARDL model can be transformed into one with only lagged order explanatory variable(s) that go back into the infinite past [76,77]. In this case, the F-statistic was applied to the joint significance so that the coefficients of the lagged variables would be zero. The hypothesis that the coefficients of the lag level variables are zero was tested. The null of non-existence of long-run relationship is defined by:

H0. $\delta_{1}=\delta_{2}=0$ (null, i.e., the long-term relationship does not exist).

H1. $\delta_{1} \neq \delta_{2} \neq 0$ (alternative, i.e., the long-term relationship exists).

This was tested in each of the models as specified by the number of variables. A Granger causality test was then conducted to determine the direction of causation between two variables. The Granger causality test was fitted with annual data from 1981 to 2019 to test the direction of causation between:

1. The federal government capital expenditure (LGCEXP) and real GDP (LRGDP),

2. The recurrent expenditure on construction sector (LREXPC) and real GDP (LRGDP), and

3. The federal government capital expenditure (LGCEXP) and recurrent expenditure on construction sector (LREXPC).

In all cases, the test also determined if feedback effects occur between comparable variables. The analysis process was done using E-views, version 10 econometric software package for economic and financial data.

\section{Results and Discussion}

\subsection{Descriptive Statistics}

From the graphical representation of the study variables shown in Figure 1, it can be deduced that all the variables exhibit an upward trend for the period. The real GDP portrays a sluggish growth within the period; the capital expenditure has been on a steady increase, while the recurrent expenditure dwindles.

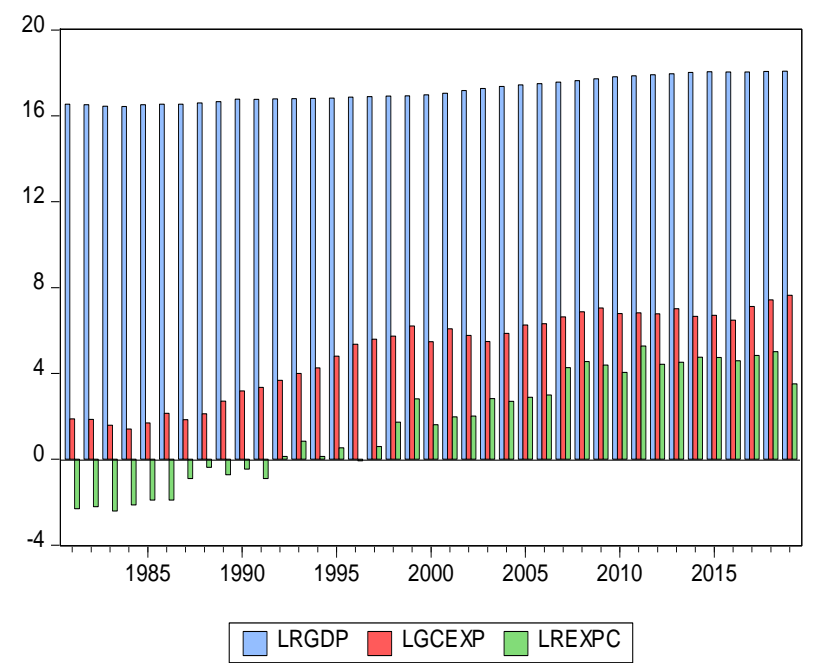

Figure 1. Graphical Representation of the research variables 
Table 1. Descriptive estimate of the research variables

\begin{tabular}{cccc}
\hline $\begin{array}{c}\text { Estimated } \\
\text { parameters }\end{array}$ & LRGDP & LGCEXP & LREXPC \\
\hline Mean & 17.20022 & 4.991628 & 1.704027 \\
Median & 16.98049 & 5.733406 & 1.974081 \\
Maximum & 18.08364 & 7.644919 & 5.277604 \\
Minimum & 16.43867 & 1.410987 & -2.407946 \\
Std. Dev. & 0.572892 & 2.013766 & 2.521850 \\
Skewness & 0.299336 & -0.570066 & -0.178121 \\
Kurtosis & 1.576618 & 1.823001 & 1.647746 \\
Jarque-Bera & 3.874689 & 4.363493 & 3.177685 \\
Probability & 0.144086 & 0.112844 & 0.204162 \\
Sum & 670.8085 & 194.6735 & 66.45706 \\
Sum Sq. Dev. & 12.47178 & 154.0996 & 241.6697 \\
Observations & 39 & 39 & 39 \\
\hline
\end{tabular}

Source: Author's computation (2020)

The descriptive estimate of the study variables shown in Table 1 indicates that for the time period, the series of the Nigerian real GDP is positively skewed, while that of federal government's capital expenditure and recurrent expenditure on construction is clustered on the left tail of the distribution. There is no excess kurtosis $(\mathrm{k}>3.0)$ in the data series of all the variables. The standard deviations are marginally different from zero, indicating that the data series are highly volatile. However, the Jarque-Bera goodness-of-fit estimate (with $\mathrm{p}>0.05$ ) confirms that the data series are statistically different from zero, and hence, follows a normal distribution.

\subsection{Stationarity Test Results Using DF-GLS, ADF, and PPApproaches}

As shown in the DF-GLS unit root test in Table 2 (with constant and trend in the model), all the variables are stationary at first differencing. This case is similar with the intercept only model, as all the variables are equally stationary at first differencing. That is to say, they are integrated of order one (i.e. (I(1))). The implication is that, using the DF-GLS unit root test approach, the two models (i.e. with intercept only, and with intercept and trend), are fit for ascertaining the level of stationarity of the variables.

Table 2. Summary of DF-GLS unit root test

\begin{tabular}{cccccccc}
\hline & & \multicolumn{2}{c}{ @Level Form } & \multicolumn{3}{c}{ @ 1 ${ }^{\text {st }}$ Differencing } \\
\hline \multirow{2}{*}{ Model } & Variable & DF-Stat & CV @ 5\% & S or NS & DF-Stat & CV @ 5\% & S or NS \\
& LRGDP & -1.824 & -3.190 & NS & $-3.302^{* *}$ & -3.190 & S \\
\multirow{3}{*}{ Intercept \& Trend } & LGCEXP & -1.475 & -3.190 & NS & $-6.355^{* *}$ & -3.190 & $\mathrm{~S}$ \\
& LREXPC & -2.698 & -3.190 & NS & $-6.894^{* *}$ & -3.190 & $\mathrm{~S}$ \\
& LRGDP & 0.006 & -1.950 & NS & $-2.808^{* *}$ & -1.950 & $\mathrm{~S}$ \\
Intercept only & LGCEXP & 0.400 & -1.950 & NS & $-6.202^{* *}$ & -1.950 & $\mathrm{~S}$ \\
& LREXPC & -0.573 & -1.950 & NS & $-6.613^{* *}$ & -1.950 & $\mathrm{~S}$ \\
\hline
\end{tabular}

** Indicates stationary at 5\% level of significance; NS = Non-stationary, S = Stationary; L = Logarithm transformation

Source: Author's Extract from E-views 10 output

Table 3. Summary of Augmented Dickey-Fuller (ADF) unit root test

\begin{tabular}{|c|c|c|c|c|c|c|c|c|c|}
\hline \multirow[b]{2}{*}{ Model } & \multirow[b]{2}{*}{ Variable } & \multicolumn{3}{|c|}{ @Level Form } & \multicolumn{5}{|c|}{ @ 1 ${ }^{\text {st }}$ Differencing } \\
\hline & & $\begin{array}{l}\text { ADF-Sta } \\
\text { t. }\end{array}$ & $\begin{array}{c}\text { CV } \\
@ 5 \%\end{array}$ & p-value & S/NS & ADF-Stat. & CV @5\% & p-value & S/NS \\
\hline \multirow{3}{*}{$\begin{array}{l}\text { Constant \& } \\
\text { Trend }\end{array}$} & LRGDP & -1.483 & -3.540 & $0.82>0.05$ & NS & $-3.323 * *$ & -3.534 & $0.08>0.05$ & NS \\
\hline & LGCEXP & -1.392 & -3.533 & $0.85>0.05$ & NS & $-6.331 * *$ & -3.534 & $0.00<0.05$ & $\mathrm{~S}$ \\
\hline & LREXPC & -2.372 & -3.533 & $0.39>0.05$ & NS & $-7.016^{* *}$ & -3.534 & $0.00<0.05$ & S \\
\hline \multirow{3}{*}{ Constant only } & LRGDP & -0.109 & -2.943 & $0.94>0.05$ & NS & $-3.408^{* *}$ & -2.943 & $0.02<0.05$ & S \\
\hline & LGCEXP & -0.834 & -2.941 & $0.80>0.05$ & NS & $-6.363^{* *}$ & -2.943 & $0.00<0.05$ & S \\
\hline & LREXPC & -1.453 & -2.941 & $0.55>0.05$ & NS & $-6.940^{* *}$ & -2.943 & $0.00<0.05$ & S \\
\hline \multirow{3}{*}{$\begin{array}{c}\text { No } \\
\text { constant, No } \\
\text { trend }\end{array}$} & LRGDP & 2.519 & -1.950 & $0.99>0.05$ & NS & $-2.139 * *$ & -1.950 & $0.03<0.05$ & S \\
\hline & LGCEXP & 2.288 & -1.950 & $0.99>0.05$ & NS & $-2.898^{* *}$ & -1.950 & $0.01<0.05$ & S \\
\hline & LREXPC & -0.374 & -1.950 & $0.54>0.05$ & NS & $-6.486^{* *}$ & -1.950 & $0.00<0.05$ & S \\
\hline
\end{tabular}

** Indicates stationary at $5 \%$ level of significance; NS = Non-stationary, S = Stationary; L = Logarithm transformation

Source: Author's Extract from E-views 10 output 
Table 4. Summary of Phillips-Perron (PP) unit root test

\begin{tabular}{|c|c|c|c|c|c|c|c|c|c|}
\hline \multirow[b]{2}{*}{ Model } & \multirow[b]{2}{*}{ Variable } & \multicolumn{2}{|c|}{ @level form } & \multicolumn{6}{|c|}{ @ 1 ${ }^{\text {st }}$ Differencing } \\
\hline & & PP-Stat. & $\begin{array}{c}\mathbf{C V} \\
@ 5 \%\end{array}$ & p-value & $\begin{array}{c}\mathrm{S} / \mathbf{N} \\
\mathrm{S}\end{array}$ & PP-Stat. & $\begin{array}{c}\mathbf{C V} \\
@ 5 \%\end{array}$ & p-value & S/NS \\
\hline \multirow{4}{*}{$\begin{array}{l}\text { Constant \& } \\
\text { Trend }\end{array}$} & LRGDP & -2.553 & -3.533 & $0.30>0.05$ & NS & $-3.204 * *$ & -3.537 & $0.10>0.05$ & NS \\
\hline & LGCEXP & -1.525 & -3.533 & $0.80>0.05$ & NS & $-6.330 * *$ & -3.537 & $0.00<0.05$ & $\mathrm{~S}$ \\
\hline & LREXPC & -2.325 & -3.533 & $0.41>0.05$ & NS & $-11.269^{* *}$ & -3.537 & $0.00<0.05$ & $\mathrm{~S}$ \\
\hline & LRGDP & 0.557 & -2.941 & $0.99>0.05$ & NS & $-3.256 * *$ & -2.943 & $0.02<0.05$ & $\mathrm{~S}$ \\
\hline \multirow[t]{3}{*}{ Constant only } & LGCEXP & -0.831 & -2.941 & $0.80>0.05$ & NS & $-6.358 * *$ & -2.943 & $0.00<0.05$ & “ \\
\hline & LREXPC & -1.630 & -2.941 & $0.46>0.05$ & NS & $-7.326^{* *}$ & -2.943 & $0.00<0.05$ & “ \\
\hline & LRGDP & 4.229 & -1.950 & $1.00>0.05$ & NS & $-1.911 * *$ & -1.950 & $0.05>0.05$ & NS \\
\hline \multirow{2}{*}{$\begin{array}{c}\text { No constant No } \\
\text { trend }\end{array}$} & LGCEXP & 2.049 & -1.950 & $0.99>0.05$ & NS & $-5.498 * *$ & -1.950 & $0.00<0.05$ & $S$ \\
\hline & LREXPC & -0.254 & -1.950 & $0.59>0.05$ & NS & $-6.489 * *$ & -1.950 & $0.00<0.05$ & $\mathrm{~S}$ \\
\hline
\end{tabular}

** Indicates stationary at 5\% level of significance; NS = Non-stationary, S = Stationary; L = Logarithm transformation

Source: Author's Extract from E-views 10 output

From the result in Table 3, the research variables are non-stationary at level form using the three unit root models. However, at first differencing, they are all stationary at 5\% level, using the unit root model with constant only, and with no constant and no trend. Hence, they have constant mean and variance at order one (i.e., $\mathrm{I}(1)$ ). But in the model with constant and trend, the real GDP was non-stationary even after first differencing at 5\% level. By implication, the unit root test model with constant and trend is not fit for real GDP for the period under review.

As shown in Table 4, the unit tests using Phillips-Perron (PP) approach with various possible models: constant and trend, constant only, and no constant and no trend All the variables were non-stationary at level form. At first differencing, the variables (with only constant in the model) were stationary. With constant and trend, and with no constant and no trend, the real GDP was non-stationary at 5\% level. The implication is that, using the Phillips-Perron (PP) unit root test approach, it is more appropriate to use the unit root model with constant only.

Since the stationarity test results in Tables 2, 3 and 4 indicated that the variables were stationary at first differencing (i.e. I(1)), the study made the choice of Autoregressive Distributed Lag (ARDL) mechanism over the Ordinary Least Squares (OLS) regression analysis technique. The ARDL long and short run estimate is laid thus in Table 5.

\subsection{Cointegration Bound Test}

The ARDL $(2,0,3)$ bound test result in Table 5 shows that the federal government capital expenditure (LGCEXP) with t-statistic value of -2.837 and $p$-value of $0.0084<0.05$ has a long-run and short-run negative and significant influence on economic growth, while the recurrent expenditure on construction sector (LREXPC) with $\mathrm{t}$-statistic value of 10.315 and $\mathrm{p}$-value of $0.0000<0.05$ is a positive driver of economic growth in Nigeria. Evidently, the result indicates that government capital expenditure saps the growth of Nigerian economy by about $10.7 \%$ while the recurrent expenditure on construction lends about $30.6 \%$ contribution to the growth of Nigerian economy. The explanatory power of the model is $99.8 \%$, indicating that the model is a good one and that about $99.8 \%$ of the total variations in the economic growth in Nigeria could be explained by the construction sector investments. This also implies that the aggregate construction investments through its multiple linkages with all sectors of the economy have potential to grow the Nigerian economy in term of its contribution to the GDP. 
Table 5. Auto-Regressive Distributed Lag (ARDL) cointegration bound test result

\begin{tabular}{|c|c|c|c|c|c|}
\hline \multicolumn{6}{|c|}{ Dependent Variable: LRGDP } \\
\hline \multicolumn{6}{|c|}{ Number of models evaluated: 100} \\
\hline \multicolumn{6}{|c|}{ Selected Model: $\operatorname{ARDL}(2,0,3) ; \operatorname{AIC}$ of the selected model $=-4.170$} \\
\hline \multicolumn{6}{|l|}{ Model summary } \\
\hline \multicolumn{6}{|l|}{$\mathrm{R}^{2}=99.8 \%$} \\
\hline \multicolumn{6}{|l|}{ Adj. $R^{2}=99.8 \%$} \\
\hline \multicolumn{6}{|l|}{ F-stat. $=2080.929$} \\
\hline \multicolumn{6}{|c|}{$\operatorname{Prob}($ F-stat. $)=0.0000$} \\
\hline \multicolumn{6}{|l|}{ D-W stat. $=2.035$} \\
\hline Variable & Lag length & Coefficient & Std. Error & t-Statistic & P-value \\
\hline LRGDP & 2 & -0.307233 & 0.121131 & -2.536379 & 0.0171 \\
\hline LGCEXP & 0 & -0.107067 & 0.037732 & -2.837524 & 0.0084 \\
\hline LREXPC & 3 & 0.306030 & 0.029668 & 10.31507 & 0.0000 \\
\hline $\mathrm{C}$ & & 17.42763 & 0.156271 & 111.5215 & 0.0000 \\
\hline $\operatorname{ECM}(-1)$ & & -0.196026 & 0.032558 & -6.020881 & 0.0000 \\
\hline \multicolumn{6}{|c|}{ Long-run bound test estimate } \\
\hline F-statistic & & 8.19 & & & \\
\hline Lower bound $(\mathrm{I}(0))$ & & 3.10 & & & \\
\hline Upper bound (I(1)) & & 3.87 & & & \\
\hline
\end{tabular}

Source: Author's extract from Eviews 10 Result

The F-statistics with probability value of $0.0000<0.05$ indicates a joint significant influence of the construction sector investments towards economic growth in Nigeria. Durbin-Watson statistic value of 2.035 that follows the rule of thumb is an indication that the model is free from first order autocorrelation problem. However, there is a long-run equilibrium relationship between construction sector investments and economic growth in Nigeria $(\mathrm{F}=8.19>\mathrm{I}(0)=3.10$ and $\mathrm{I}(1)=3.87)$. The Error Correction Estimate appeared with the expected (negative) sign $(\operatorname{ECM}(-1)=-0.196, \mathrm{p}=0.000<0.05)$. The result shows that about $19.6 \%$ of the disequilibrium between construction sector investments and economic growth in Nigeria can be corrected in one year. This implies that it would take about 5 years for the economic growth to be restored to a long-run equilibrium state if the federal government capital and recurrent expenditures triggered any shock in the construction sector. The model is given as follows:

EC $=$ LRGDP $-(-0.1071 *$ LGCEXP + 0.3060*LREXPC + 17.4276)
Although this model confirmed that the overall public investments in the construction sector positively influence the economic growth in Nigeria, but the huge federal government capital expenditure has not impacted the economy positively. This study shows that within the period under study, the economic growth in Nigeria has not measured up with the capital expenditure signifying that the capital expenditure was not directed towards growing the Nigerian economy. A pointer to this fact is the percentage contribution of construction sector to the real GDP within the period under study.

\subsection{Diagnostic Test}

Table 6. Residual Diagnostic Test Results

\begin{tabular}{ccc}
\hline Type of Test & Test statistic & P-value \\
\hline $\begin{array}{c}\text { Residual Normality test } \\
\begin{array}{c}\text { Residual } \\
\text { Heteroskedasticity test }\end{array}\end{array}$ & J-B stat. $=0.226$ & 0.8933 \\
\hline
\end{tabular}

Source: Author's extract from Eviews 10.0 output 


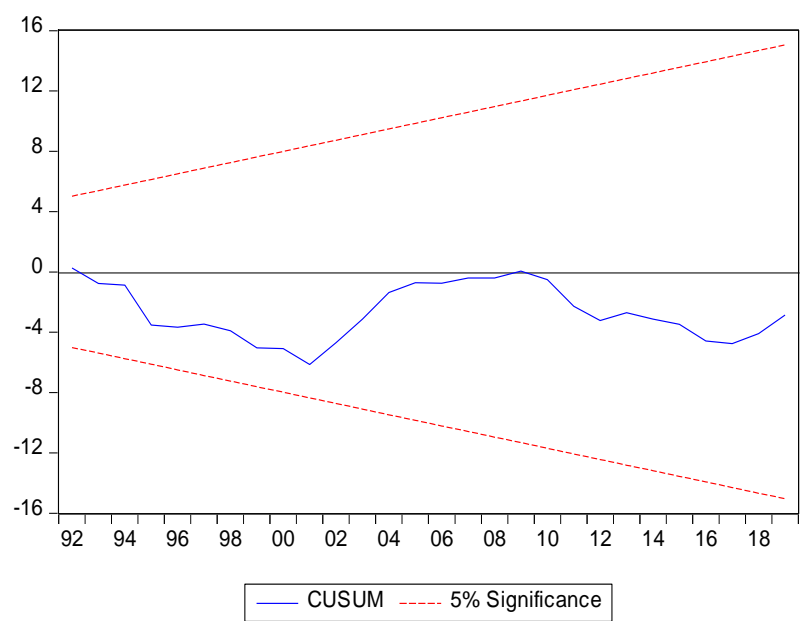

Figure 2. Stability Test

Table 7. Model Specification Test Result

Ramsey RESET Test

Equation: UNTITLED

Specification: LRGDP LRGDP(-1) LRGDP(-2) LGCEXP LREXPC

LREXPC(-1) LREXPC(-2) LREXPC(-3) C

Omitted Variables: Squares of fitted values

\begin{tabular}{cccc} 
& Value & df & Probability \\
\cline { 2 - 4 } t-statistic & 0.096838 & 27 & 0.9236 \\
F-statistic & 0.009378 & $(1,27)$ & 0.9236
\end{tabular}

F-test summary:

\begin{tabular}{cccc} 
& Sum of Sq. & df & $\begin{array}{c}\text { Mean } \\
\text { Squares }\end{array}$ \\
\cline { 2 - 4 } Test SSR & $7.25 \mathrm{E}-06$ & 1 & $7.25 \mathrm{E}-06$ \\
Restricted SSR & 0.020880 & 28 & 0.000746 \\
Unrestricted SSR & 0.020873 & 27 & 0.000773 \\
\hline
\end{tabular}

Source: Author's computation from Eviews 10 Result

Table 6 indicates that the residual series are normally distributed and homoscedastic. In this case, the p-values based on Jarque-Bera and Breusch-Pagan-Godfrey respectively are greater than critical value $(p>0.05)$. This implies that the estimated regression results are not misleading or spurious. Furthermore, the cumulative sum (CUSUM) recursive test shows that the series estimates are within limits as shown in Figure 2. Hence, they can be used for forecasting. The Ramsey Regression Error Specification test (RESET) result presented in Table 7 further confirms that the model is correctly specified $(p=0.9236>0.05)$ and that the regression estimates are accurate and reliable.

\subsection{Granger Causality Test}

From the Granger causality test result presented in Table 8 , the recurrent expenditure on construction sector is a significant driver of economic growth in Nigeria $(p=0.0225<0.05) \quad$ without a feedback, while a unidirectional relationship runs from the government capital expenditure to recurrent expenditure on construction sector $(p=0.0434<0.05)$. Moreover, there is no causal relationship between government capital expenditure and GDP $(p>0.05)$ for the study period. Since the federal government capital expenditure granger causes the recurrent expenditure on construction sector, it implies that government capital expenditure is only an indirect influencer of economic growth. This therefore, authenticates the joint positive influence of overall public investments in construction sector on economic growth in Nigeria.

Table 8. Granger Causality Test Result

Pairwise Granger Causality Tests

Sample: 19812019

Lags: 2

Null Hypothesis:

Obs F-Statistic Prob.

$\begin{array}{llll}\text { LGCEXP does not Granger Cause LRGDP } & 37 & 1.15339 & 0.3283 \\ \text { LRGDP does not Granger Cause LGCEXP } & & 0.12678 & 0.8814\end{array}$

LREXPC does not Granger Cause LRGDP

37

$4.28287 \quad 0.0225$

LRGDP does not Granger Cause LREXPC

$0.70188 \quad 0.5031$

$\begin{array}{lrrr}\text { LREXPC does not Granger Cause LGCEXP } & 37 & 0.45298 & 0.6397 \\ \text { LGCEXP does not Granger Cause LREXPC } & 3.46515 & 0.0434\end{array}$

Source: Author's Eviews 10 Result

Fundamentally, public investments in construction sector are expected to bring about economic growth and development. Unfortunately, this study demonstrated that federal government capital expenditure negatively influences economic growth in Nigeria. This part of results is aligned with [60] who attributed the result to corruption in the procurement and implementation of capital projects. It also supports the result of [61]. On the other hand, this study found that the recurrent expenditure on construction sector has a positive and significant long-run and short-run influence economic growth in Nigeria. This result shows alliance with $[29,57,58]$. This 
particular result is not surprising in that most of recurrent expenditure goes directly to servicing people (e.g. wages and salaries) and other things related to human services and improvements which indirectly flow into the economy. However, the study established that aggregate public investments in construction sector in terms of federal government capital expenditure and recurrent expenditure on construction sector have potential to grow the Nigerian economy regardless of the effects of capital expenditure. It shows that about $99.8 \%$ of aggregate economy in terms of real GDP could be explained by the overall public investments in construction sector.

Notwithstanding, this study shows that there is no causal relationship between federal government capital expenditure and economic growth, rather a unidirectional flow to the recurrent expenditure on construction sector. It also shows that recurrent expenditure on construction sector granger causes real GDP without feedback. This therefore, implies that while capital expenditure does not have direct positive influence on economic growth, the recurrent expenditure on construction sector does. But overall, public investments in construction sector influence the economy positively through the combined indirect influence of capital expenditure.

Since the variables are integrated of the same order (I(1), the cointegration result confirms that the variables are cointegrated. It also indicated that aggregate public investments in construction sector have both short-run, and a stable long-run contemporaneous equilibrium relationship with the economic growth in Nigeria. It further signifies that economic growth through the real GDP can be predicted from the aggregate public investments in construction sector and that growth is mainly dependent on the investments. The cumulative sum (CUSUM) stability test confirms that the relationship is stable over a long period of time as about $99.8 \%$ of proportion of variation in economic growth can be explained by the combined effect of construction investments.

The Error Correction Estimate however, indicates that the deviation from the equilibrium level in the current year would be corrected by $19.6 \%$ in the following year. It signifies that a long-run equilibrium state would be restored on the economic growth after about 5 years if there is any deviation in the system as a result of shock caused by the federal government capital expenditure and recurrent expenditure on construction sector. This suggests that aggregate public investments in construction sector are economic variables and that economic growth is sensitive to investments in the construction sector. Theoretically, within the period under review, this study partly supports the existence of Keynesian theory in Nigeria, but completely could not establish the existence of Wagner's Law in Nigeria due to reasons adduced earlier. Although these results present a complex but interesting scenario, it suggests that huge annual federal government capital expenditure is being misapplied and have not been directed towards the growth of the economy. It therefore, raises posers for policy makers and economic planners in Nigeria.

\section{Conclusions}

The debate over the role of construction sector toward the growth of national economy and the feedback effects of national economy on construction sector in Nigeria has been ravaging. As a contribution to this debate, this study empirically investigated the relationship between public investments in the construction sector and economic growth in Nigeria. The study found that federal government capital expenditure has a long-run and short-run negative and significant influence on economic growth. Whereas, the recurrent expenditure on construction sector has a positive and significant long-run and short-run influence economic growth with a causal effect flowing from recurrent expenditure on construction sector to real GDP without feedback. However, it established that aggregate public investments in the construction sector in terms of federal government capital expenditure and recurrent expenditure on construction sector have potentials to grow the Nigerian economy regardless of the effects of capital expenditure. It further found that investments in the construction sector can be used to predict the growth in Nigerian economy.

Since the aggregate construction expenditure shows potentials for improving the economy, this study therefore, raises many questions that desired some answers. It shows that Nigerian economic models are defective or ineffective in transforming the huge capital spending on construction to economic growth and making investments in the construction sector a tool for economic and policy planning. This study points to the misapplication or misplacement of prioritisation of capital budget in Nigeria. It contends that between planning and implementation of capital budget, there is a missing link. The value of this study therefore, rests on its results. It is a pointer for economic planners and those responsible for government capital budget implementation and monitoring to look beyond the mere presentation of budget. Theoretically, the study has revealed the actual performance of federal government capital spending and recurrent spending on construction sector. Finally, this study places the burden of economic rejuvenation through investment in the construction sector on the economic policy and decision makers in Nigeria. It recommends for diligence in budgeting and implementation of capital projects as the only way public investments in the construction sector can contribute to economic value and growth in Nigeria. The result of this study therefore, calls for further investigation because within the period of study, there were booms and falls in the economic time series which may affect the 
outcome of this study. As a result, the relationship between public investments in the construction sector and economic growth needs to be compared within these periods.

\section{REFERENCES}

[1] Ministry of Budget and National Planning. Federal Republic of Nigeria Economic Recovery \& Growth Plan 2017-2020, Budget Office of the Federation, Abuja, 2017.

[2] C.C. Nwachukwu, F.I. Emoh. Building construction project management success as a critical issue in real estate development and investment, American Journal of Social and Management Sciences, Vol. 2, No. 1, 56-75, 2011. https://doi.org/10.5251/ajsms.2011.2.1.56.75.

[3] N. Ahmadi, M. Shahandasht. Comparative empirical analysis of temporal relationships between construction investment and economic growth in the United States, Construction Economics and Building, Vol. 17, No. 3, 85-108, 2017. https://doi.org/10.5130/AJCEB.v17i3.5482.

[4] J. Lopes, R. Olivera, M.I. Abreu. The sustainability of the construction industry in Sub-Saharan Africa: Some new evidence from recent data, Procedia Engineering, 172, 657-664, 2017. https://doi.org/10.1016/j.proeng.2017.02.07 7.

[5] Z.S. Ahmed. Highlights/breakdown of the 2020 executive budget proposal, Budget Office of the Federation, Abuja, Nigeria, 2019.

[6] Federal Ministry of Finance. 2010 budget amendment proposal, Budget Office of the Federation, Abuja, Nigeria, 2010 .

[7] Federal Ministry of Finance. Appropriation (amendment) Act 2011: Explanatory memorandum, Budget Office of the Federation, Abuja, Nigeria, 2011.

[8] Federal Ministry of Finance. Federal Republic of Nigeria 2012 budget proposal v3, Budget Office of the Federation, Abuja, Nigeria, 2012.

[9] B. Okogu. A public presentation of the 2013 FGN budget: Fiscal consolidation with inclusive growth, Budget Office of the Federation, Abuja, Nigeria, 2013.

[10] B. Okogu. A public presentation of the 2014 FGN budget: A budget for jobs and inclusive growth, Budget Office of the Federation, Abuja, Nigeria, 2014a.

[11] B. Okogu. An analysis of the 2014 FGN budget: A transition budget, Budget Office of the Federation, Abuja, Nigeria, 2014b.

[12] U.U. Udoma. Overview of the 2017 budget proposal: Budget recovery and growth, Budget Office of the Federation, Abuja, Nigeria, 2016.

[13] U.U. Udoma. Public presentation of the 2018 FGN budget: 2018 budget of consolidation, Budget Office of the Federation, Abuja, Nigeria, 2018.

[14] U.U. Udoma. Breakdown of 2019 FGN budget approved,
Public presentation of the 2019 budget of continuity, Budget Office of the Federation, Abuja, Nigeria, 2019.

[15] A. Jibir, C. Aluthge. Modelling the determinants of government expenditure in Nigeria, Cogent Economics \& Finance, Vol. 7, No. 1, 1620154, 2019.https://doi.org/10.10 $80 / 23322039.2019 .1620154$

[16] S.A. Babatunde. Government spending on infrastructure and economic growth in Nigeria, Economic Research Ekonomska Istraživanja, Vol. 31, No. 1, 997-1014, 2018. https://doi.org/10.1080/1331677X.2018.1436453.

[17] O. Owoeye. How Nigeria's construction sector slows despite claims of increased government spending, Business Day Newspaper, February 13, 2019.

[18] G. Dang, L.S. Pheng. Infrastructure investments in developing economies: The case of Vietnam, Springer, Singapore, 2015. https://doi.org/10.1007/978-981-287-2487.

[19] T.O. Oladinrin, D.R. Ogunsemi, I.O. Aje. Role of construction sector in economic growth: Empirical evidence from Nigeria, FUTY Journal of the Environment, Vol. 7, No. 1, 50-60, 2012. https://doi.org/10.4314/fje.v7i1.4.

[20] S. Chan, Z. Ramly, M. Abdkarim, Government spending efficiency on economic growth: Roles of value-added tax, Perspectives on East Asian Economics and Industries, Vol. 46, No. 2, 162-188, 2017.

[21] A.I. Babalola. Fiscal policy and economic development in Nigeria. Journal of Economic and Sustainable Development, Vol. 6, No. 7, 150-160, 2015.

[22] B. Satope, B. Akanbi. Effect of businesses on economic development in Nigeria, E3 Journal of Business Management and Economics, Vol. 5, No. 4, 091-096, 2014.

[23] C.O. Omodero. Analysis of factors influencing public capital investment in Nigeria. Journal of Educational and Social Research, Vol. 10, No. 1, 62, 2020.https://doi.org/10.36941 /jesr-2020-0007.

[24] NBS. Nigerian construction sector summary report: 20102012, National Bureau of Statistics, Abuja, 2015.

[25] J. Bello-Schünemann, A. Porter. Building the future infrastructure in Nigeria until 2040, West African report, Institute for Security Studies, Pretoria, South Africa, 2017.

[26] M. Connolly, C. Li. Government spending and economic growth in the OECD countries, Journal of Economic Policy Reform, Vol. 19, No. 4, 386-395, 2016. https://doi.org/10.1 080/17487870.2016.1213168.

[27] S. Raheem, J.O. Ayana, A.O. Fasedemi. Easing the "disease" of poverty in Nigeria, Developing Country Studies, Vol. 4, No. 19, 55-66, 2014.

[28] D.T.H. Giang, L.S. Pheng. Role of construction in economic development: Review of key concepts in the past 40 years. Habitat International, Vol. 35, No. 1, 118-125, 2011. https://doi.org/10.1016/j.habitatint.2010.06.003.

[29] M. Idris, R. Bakar. Public sector spending and economic growth in Nigeria: In search of a stable relationship. Asian Research Journal of Arts and Social Sciences, Vol. 3, No. 2, 1-19, 2017. https://doi.org/10.9734/ARJASS/2017/33363.

[30] L.S. Oyediran, I. Sanni, L. Adedoyin, O.M. Oyewole. 
Government expenditure and economic growth nexus: Evidence from Nigeria, Business and Management Research, Vol. 5, No. 4, 56-61, 2016. https://dx.doi.org.10.5430/bmr.v n4p56.

[31] S.S. Molapo. Analysis of public expenditure growth on infrastructure in Lesotho, The Macroeconomic and Financial Management Institute of Eastern and Southern Africa (MEFMI) Working Paper, 2017. Online available from http://www.mefmi.org/images/effect-of-public-expenditure. ...,2017.

[32] D. Girardi, A. Mura. Construction and economic development: Evidence for the period 2000-2011, Quaderni del Dipartmento di Economia Politica e Statistica, Univeritò di Siena, Italy, 2013.

[33] D. Girardi, A. Mura. Construction - development curve: Evidence from a new international dataset, The IUP Journal of Applied Economics, Vol. 13, No. 3, 2014.

[34] C.F. Choy. Revisiting the 'Bon curve', Construction Management and Economics, Vol. 29, No. 7, 986-712, 2011. https://doi.org/10.1080/01446193.2011.578959.

[35] L.S. Pheng, L.S. Hou. The economy and the construction. In: Construction quality and the economy. Management in the built environment, Springer, Singapore, 2019. https://doi.org/10.1007/978-981-287-13-5847-0_2.

[36] C. Liu, S. He. Input-output structures of the Australian construction industry, Construction Economics and Building, Vol. 16, No. 2, 56-70, 2016. https://doi.org/10.5130/AJCEB .v16i2.48129.

[37] X. Ma, C. Huang, Y. Fu, J. Gao, B. Qin. Study on evolution of China's construction industry based on input-output analysis and complex network, Technical Gazette, Vol. 26, No. 1, 208-216, 2019. https://doi.org/10.17559TV-2018121 9145712 .

[38] A. Wagner. Three extracts from public finance. In: R.A. Musgrave, A.T. Peacock (eds.), Classics in the theory of public finance, International Economic Association Series. Palgrave Macmillan London, 1-15, 1958. https://doi.org/10. 1007/978-1349-23426-4_1.

[39] L. Kónya. B. Abdullaev. An attempt to restore Wagner's law of increasing state activity, Empirical Economics, Vol. 55. 1569-1583, 2018. https://doi.org/10.1007/s00181-017-1339 $-\mathrm{X}$.

[40] T.G. Monogbe, O.J. Okah. Government spending and economic growth process in Nigeria, frontiers of Accounting and Finance, Vol. 2, No. 1, 1-9, 2017. https://dx.doi.org/10.20936/FAF/170101.

[41] Oxford Business Group. Planned spending by the Nigerian government set to boost construction sector, In: The report: Nigeria 2016: Construction and real estate. Oxford Business Group, London, 2020. Online available from https://oxfordbusinessgroup.com/nigeria-2016/constructionreal-estate.

[42] J.M. Keynes. The general theory of employment, interest and money, Macmillan, London, 1936.

[43] M. Cosmos, G. Lorenzo, M. Macro. Wagner's law and Peacock and Wiseman displacement effect in European Union countries: A panel data study, International Journal of
Economics and Financial Issues, Vol. 5, No. 3, 812-819, 2015.

[44] S.S. Awode, E.O. Akpa. Testing Wagner's law in Nigeria in the short and long-run. Acta Universitatis Danubius. Economica, Vol. 14, No. 7, 7-23, 2018.

[45] V.E. Awuh. The composition of public expenditure: Does it matter for growth? Master of Science Thesis, Department of Economics, University of San Francisco, CA, 2018. Online available from https://repository.usfa.edu/thes/1072.

[46] N. Berk, S. Biçen. Causality between the construction sector and GDP growth in emerging countries: The case of Turkey, Athens Journal of Mediterranean Studies, Vol. 4, No. 1, 19-36, 2018. https://doi.org/10.30958/ajms.4-1-2.

[47] L Pula. A. Elshani. Role of government expenditure in economic growth. Econometric evidence from Kosova 2002-2015, Baltic Journal of Real Estate Economics and Construction Management, Vol. 6, 74-87, 2018 https://doi.org/10.2478/bjreecm-2018-0006.

[48] O.S. Aigheyisi. The relative impacts of federal capital and recurrent expenditures on Nigeria's economy (1980-2011), American Journal of Economics, Vol. 3, No. 5, 210-221, 2013. https://doi.org.10.5923/j.economics.20130305.02.

[49] A.K. Chijioke, A.I. Amadi. Government expenditure on infrastructure as a driver for economic growth in Nigeria, Journal of International Business Research and Marketing, Vol. 5, No. 2, 20-26, 2020. http://dx.doi.org/10.18775/jibrm .1849-8558.2015.52.3004.

[50] G.E. Edame, C.C. Udude, U.D. Ugwu. An analysis of public expenditure growth on infrastructure in Nigeria, International Journal of Humanities, Social Sciences and Education, Vol. 1, No. 12, 18-36, 2014.

[51] E. Iheanacho. The contribution of government expenditure on economic growth of Nigeria: Disaggregated approach, International Journal of Economics \& management sciences, Vol. 5, No. 5, 1-9, 2016. https://doi.org/10.4172/2162-6359 .1000369 .

[52] O.A. Ihensekhien, J.G. Mayuku, Government expenditures in Nigeria: Re-examination of Wagner's law, Journal of Economics and Political Economics, Vol. 6, No. 2, 143-158, 2019. https://dx.doi.org/10.1453/jepe.v6ie.1874.

[53] S.T. Onifade, S.Çevik, S. Erdoğan, S. Asongu, F.V. Bekun, An empirical retrospect of the impacts of government expenditures on economic growth: New evidence from the Nigerian economy, Journal of Economic Structures, Vol. 9, No. 6, 2020. https://doi.org.10.1186/s40008-20-0186-7.

[54] A.O. Olanikpekun, N. Saka. Response of the Nigerian construction sector to economic shocks, Construction Economics and Building, Vol. 19, No. 2, 160-180, 2019. https://doi.org/10.5130/AJCEB.v19i2.6667.

[55] N.A. Darma. Federal capital expenditure and its impact on economic growth in Nigeria: 1980-2010, Developing Country Studies, Vol. 4, No. 4, 24-33, 2014.

[56] P.B. Eregha, P.S. Sede, F.O. Onotaniyohwo. Does the composition of public expenditure matter for growth in Nigeria? A vector error correction approach, Pakistan Journal of Social Sciences, Vol. 9, No. 3, 125-131, 2012. https://doi.org/10.3923/pjssci.2012.125.131. 
[57] D.B. Ewubare, S.L. Maeba, Effect of public expenditure in construction and transportation sectors on employment in Nigeria, International Journal of Science and Management Studies, Vol. 1, No. 4, 130-136, 2018.

[58] S.I. Osheni. Empirical examination of the effects of government spending on the GDP growth rates of Nigeria, Indian Journal of Commerce and Management Studies, Vol. 9, No. 3, 26-31, 2018. https://doi.org.10.18843/ijcms/v9i3/0 4 .

[59] C.I. Anoke, S.I. Odo, B.C. Chukwu, P.E. Agbi. Testing the application of Wagner's law in Nigeria. Journal of Research in Business and Management, Vol. 4, 6, 33-45, 2016.

[60] S.I. Odo, J.O. Nwachukwu, P.E. Agbi, T.O. Okoro. Analysis of government expenditure and economic growth in Nigeria: Application of cointegration methodology, Asian Research Journal of Arts and Social Sciences, Vol. 1, No. 4, 1-17, 2016. https://doi.org/10.9734/ARJASS/2016/29486.

[61] D. Charles, O. Onuchukwu, S.O. Tamuno. Government expenditure on construction, transport and communication and economic growth in Nigeria, International Journal of Scientific Research, Vol. 3, No. 2, 39-47, 2018.

[62] V. Osei. The construction industry and its linkages to the Ghanaian economy-polices to improve the sector's performance, International Journal of Development and Economic Sustainability, Vol. 1, No. 1, 56-72, 2013.

[63] CBN. 2018 Statistical Bulletin: Public Finance Statistics, Central Bank of Nigeria, Abuja, Nigeria, 2019. Online available from https://www.cbn.gov.ng/documents/Statbull etin.asp.

[64] CBN. 2019 Statistical Bulletin: Public Finance Statistics, Central Bank of Nigeria, Abuja, Nigeria, 2019. Online available from https://www.cbn.gov.ng/documents/Statbull etin.asp.

[65] D.B. Ewubare, A.O. Okpani. Poverty and income inequality in Nigeria (1980- 2017), International Journal of Advanced Studies in Ecology, Development and Sustainability, Vol. 5, No. 1, 138-151, 2018.

[66] NBS. Annual abstract of statistics 2010. National Bureau of Statistics, Abuja, Nigeria, 2010. Online available from www.nigeranstat.gov.ng.
[67] NBS. Nigerian capital importation: Summary report 2007-2014, National Bureau of Statistics, Abuja, Nigeria, 2014. Online available from www.nigeranstat.gov.ng.

[68] NBS. Post GDP rebasing revision: 1981-2010, National Bureau of Statistics, Abuja, Nigeria, 2016. available from www.nigeranstat.gov.ng.

[69] NBS. Nigerian gross domestic product report (Q1 2020), National Bureau of Statistics, Abuja, Nigeria, 2020. Online available from www.nigeranstat.gov.ng.

[70] G. Elliott, T.J. Rothenberg, J.H. Stock. Efficient tests for an autoregressive unit root, Econometrica, Vol. 64, No. 4, 813 836, 1996. https://doi.org/10.2307/2171846.

[71] D.A. Dickey, W.A. Fuller. Distributions of the estimators for autoregressive time series with a unit root, Journal of the American Statistical Association, Vol. 74, No. 366, 427-431, 1979. https://doi.org/10.2307/2286348.

[72] P. Phillips, P. Perron. Testing for a unit root in time series regression, Biometrika Vol. 75, No. 2, 335-346, 1988. https://doi.org/10.2307/2336182.

[73] M.B. Shrestha, G.R. Bhatta. Selecting appropriate methodological framework for time series data analysis, The Journal of Finance and Data Science, Vol. 4, No. 2, 71-89, 2018. https://doi.org/10.1016/j.fds.2017.11.001.

[74] M. Arltová, D. Fedorová. Selection of unit root test on the basis of length of the time series and value of AR(1) parameter, Statistika, Vol. 93, No. 3, 47- 64, 2016.

[75] E. Nkoro, A.K. Uko, Autoregressive Distributed Lag (ARDL) cointegration technique: Application and interpretation, Journal of Statistical and Econometric Methods, Vol. 5, No. 3, 63-91, 2016.

[76] R.F. Engle, C.W.J. Granger. Cointegration and error correction representation, estimating and testing, Econometrica, Vol. 55, No. 2, 251-276, 1987. https://doi.org/10.2307/1913236.

[77] M.H. Pesaran, Y. Shin. An autoregressive distributed-lag modelling approach to cointegration analysis, In the Ragnar Frisch Centennial Symposium: Econometrics and Economic Theory in the 20th Century, Cambridge University Press, Cambridge, 1999. 